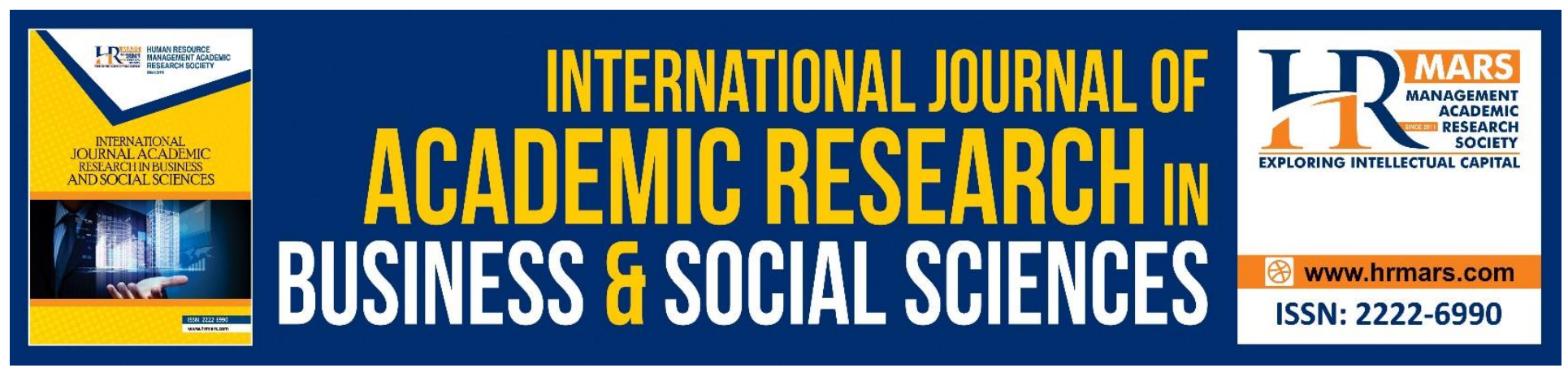

\title{
Development and Usability of Training Module on the Efficacy and Anxiety Levels of Teaching English Among Early Childhood Education Teachers
}

\section{Nur Nazuha Beevi Abdul Aziz and Nordin Mamat}

To Link this Article: http://dx.doi.org/10.6007/IJARBSS/v8-i12/5436

DOI: $10.6007 /$ IJARBSS/v8-i12/5436

Received: 16 Nov 2018, Revised: 22 Dec 2018, Accepted: 30 Dec 2018

Published Online: 14 Jan 2019

In-Text Citation: (Aziz \& Mamat, 2018)

To Cite this Article: Aziz, N. N. B. A., \& Mamat, N. (2018). Development and Usability of Training Module on the Efficacy and Anxiety Levels of Teaching English Among Early Childhood Education Teachers. International Journal of Academic Research in Business and Social Sciences, 8(12), 2250-2264.

\section{Copyright: (C) 2018 The Author(s)}

Published by Human Resource Management Academic Research Society (www.hrmars.com)

This article is published under the Creative Commons Attribution (CC BY 4.0) license. Anyone may reproduce, distribute, translate and create derivative works of this article (for both commercial and non-commercial purposes), subject to full attribution to the original publication and authors. The full terms of this license may be seen at: http://creativecommons.org/licences/by/4.0/legalcode

Vol. 8, No. 12, 2018, Pg. 2250 - 2264

Full Terms \& Conditions of access and use can be found at http://hrmars.com/index.php/pages/detail/publication-ethics 


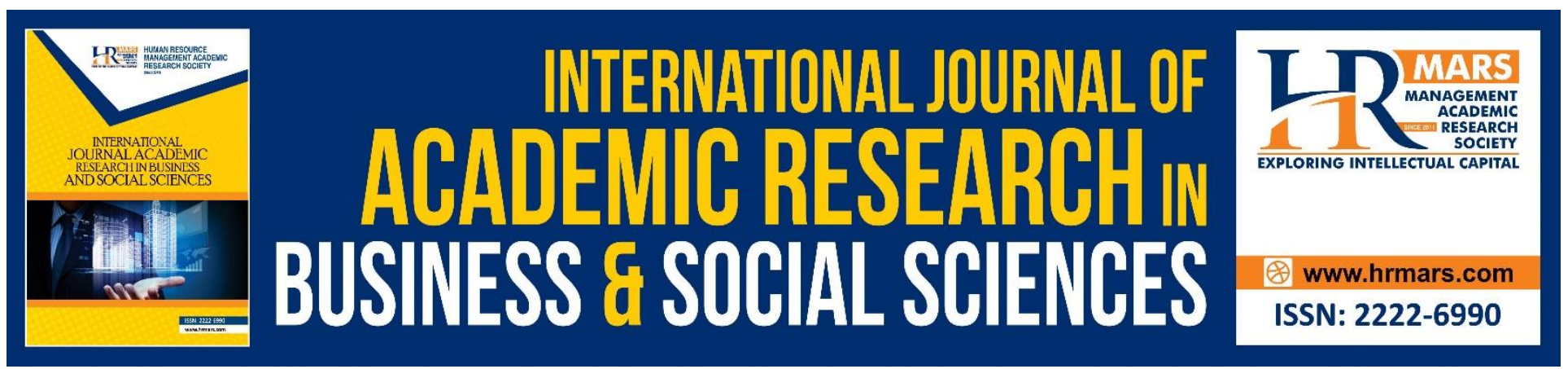

\title{
Development and Usability of Training Module on the Efficacy and Anxiety Levels of Teaching English Among Early Childhood Education Teachers
}

\author{
Nur Nazuha Beevi Abdul Aziz' and Nordin Mamat ${ }^{2}$ \\ National Child Development Research Centre, Faculty of Education and Human Development \\ Sultan Idris Education University, 35900, Tanjong Malim, Perak, Malaysia
}

\section{Abstract}

This study aims to develop a training module to improve the efficacy among the early childhood education teachers in teaching English. The Design and Development Research methodology introduced by Richey and Klein (2014) was used in this study involving 3 phases. The data from the first phase (need analysis) were collected through questionnaire distributed among 90 early childhood education teachers via purposive sampling. The findings from the closed-ended questions were analysed using Statistical Package for the Social Sciences (SPSS) version 23 whereas the openended responses were subjected to thematic analysis. The data from the second phase were obtained based on the Bandura's Self-Efficacy Theory and Keller's ARCS Model. The theory specifies that there are four main factors that affect a person's self-efficacy, namely mastered self-experience (careerwise or past failure), vicarious experience (imposing other's success on himself), verbal persuasion (feedback on tasks given), psychological and physiological reactions (stress, worry and physical strength).The Keller's ARCS Model comprises four factors, A-Attention, R-Relevance, C-Confidence dan S- Satisfaction. The draft of the module was validated based on expert views and reliability questionnaires. The third phase that involves module usability was evaluated via quasi-experiment among 66 participants. A parametric test which is t-test revealed that the teachers from treatment group performed better in terms of self-efficacy belief, teaching efficacy practice, efficacy level, anxiety level and attitude. The qualitative data obtained from interview sessions with 8 teachers and 2 facilitators were used to support the findings. The findings show that there is a need to develop Module of Efficacy Enhancement in English Teaching among the Early Childhood Education Teacher (MEET-EceT). The findings from the second phase of the design study show that the expert views exceed 80 percent while the module reliability exceeds 70 percent. The results from the module usability evaluation shows that the efficacy level in English teaching increases, the anxiety level in teaching English decreases and there is a change of attitude in teaching English (knowledge, motivation, self-confidence, behaviour). Therefore, it is concluded that the MEET-EceT training 
INTERNATIONAL JOURNAL OF ACADEMIC RESEARCH IN BUSINESS AND SOCIAL SCIENCES

Vol. 8, No. 12, Dec, 2018, E-ISSN: $2222-6990$ C 2018 HRMARS

module should be emphasised among the early childhood education teachers during teachers 'training to increase their efficacy level and decrease their anxiety level in teaching English.

Keywords: Design and Developmental Research, Training Module, Early Childhood Education Teachers, Teacher Efficacy And Teacher Anxiety.

\section{Introduction}

The Malaysia Education Blueprint 2013-2025 highlights the need to ensure that every child is proficient in at least two languages: Bahasa Malaysia and English. Fundamental to this goal is the provision of the necessary resources required for language learning, reflected in the various language-based initiatives within the Malaysian education system. While the medium of instruction in our education system remains Bahasa Malaysia, the Ministry of Education believes that the goal of bilingual capacity will be achieved if a concerted effort is made to upskill teachers and students in English proficiency.

Based on the new policy, the National Preschool Standard Curriculum (NPSC) also undergoes changes such as allocation of additional hours for English subject, up to 600 minutes a week and preschoolers need to acquire listening, reading, writing and speaking skills(National Preschool Standard Curriculum, 2010). The latest change is the English Language Education Reform, which is known as CEFR (Common European Framework of Reference for Languages). The Education Ministry had announced that starting 2018, the CEFR syllabus has kicked off in all preschool institutions. CEFR is an attempt made to for improve the students' proficiency up to the international standard by emphasising communication skill among the preschoolers.

\section{Research Background}

The PPSMI (Teaching of Science and Mathematics in English) has been abolished due to its failure to reach the expected goals, in which the performance in Science and Mathematics got worse and the teachers involved are not proficient in English. Thus, some changes have taken place in the education system. The first change is that the goverment has made a new policy of to Uphold Bahasa Malaysia and Strengthen English (MBMMBI). The Education Ministry apply comprehensive measures to improve the students' command of English via the Strengthening English (MBI) policy. Measures to improve the teaching and learning methods in English at schools were implemented by adding more hours for English subject and qualified English teachers including those who had studied abroad were hired to help polish the student proficiency in English.

Despite the changes implemented by the government, the actual situation does not meet the requirements of the Malaysian education system. The study conducted on the use of English in preschool classes found that most of the teachers are not confident in teaching English (KPM, 2010). The findings from the study on the National Preschool Standard Curriculum found that the preschool teachers do not comply with the implementation of using English while teaching in English (KPM, 2012). The report by Jemaah Nazir dan Jaminan Kualiti (JNJK) in 2012 found that preschool teachers do not adhere to the requirement in English teaching and learning. Rohaty (2013) found that the early childhood education teachers have low competence to interact in English and their English 
proficiency does not meet the standard, where they are unable to speak in English fluently and confidence to do so. This is supported by another scholar that the preschool teachers were found to have insufficient basic skills in teaching English as the second language as requested in NPSC (Mardziah Abdullah, 2017). The findings showed that the early childhood teachers have lack of skills in English due to low self-esteem and they have negative attitude towards the use of English in communication. Other findings found that the teachers have low English proficiency, limited English vocabulary, besides having lack of interest, comprehension and confidence in English (Mustafa et.al, 2018).

The English curriculum undergo so many modifications, changes and improvements so that the students in Malaysia can master the language from 4 to 6 years old. The early childhood education teachers play an important role to deliver curriculum in teaching effectively. However, the issues involving the early childhood education need to be addressed, such as lack of English proficiency, lack of content knowledge and pedagogy, limited English vocabulary, unable to speak fluently, unable to give instruction in English while teaching, negative attitude towards English, not interested with English, have no motivation to teach in English, lack of confidence and have anxiety towards English.

The Module of Efficacy Enhancement in English Teaching among the Early Childhood Education Teacher (MEET-EceT) is a training module that aims to improve the efficacy level among the early childhood education teachers in teaching English to overcome the issues that have been highlighted.

\section{Research Methodology}

This research adopts the Design and Developmental Research (DDR) (Richey \& Klein, 2014) to evaluate three main objectives. First, it is to identify the need to develop a training module for early childhood education teachers to improve their efficacy level and reduce their anxiety level in teaching English. Second, it is to develop a training module for early childhood education teachers to improve their efficacy and reduce their anxiety level in teaching English based on the Bandura's Self-Efficacy Theory and Keller's ARCS Model. Third, it is to evaluate the usability of the Module of Efficacy Enhancement in English Teaching among the Early Childhood Education Teacher (MEET-EceT) to improve their efficacy level and reduce their anxiety level in teaching English. 
INTERNATIONAL JOURNAL OF ACADEMIC RESEARCH IN BUSINESS AND SOCIAL SCIENCES Vol. 8, No. 12, Dec, 2018, E-ISSN: $2222-6990$ C 2018 HRMARS

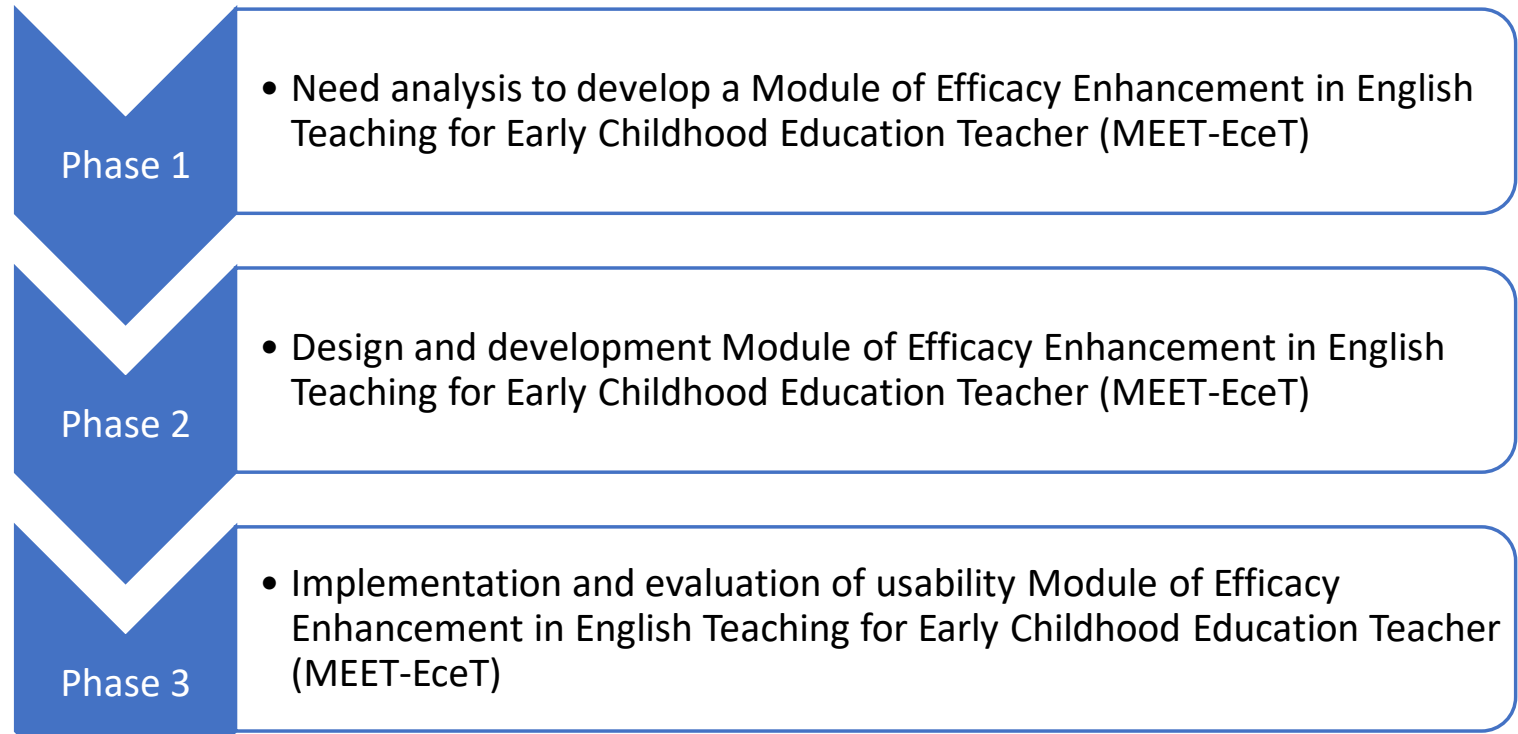

Figure 1 : Module of Efficacy Enhancement in English Teaching for Early Childhood Education Teacher (MEET-EceT) development process

\section{Result and Key Findings}

\section{i) Need Analysis Phase}

Table 1 : Mean difference and standard deviation for each domain

\begin{tabular}{|l|c|c|}
\hline \multicolumn{1}{|c|}{ Domain } & Mean Average & Std. Deviation \\
\hline Self-assessment in teaching & 2.4206 & .91970 \\
\hline Self-development of emotions & 2.5286 & .93652 \\
\hline Knowledge and achievement in English & 3.1760 & .43396 \\
\hline Self-modelling in teaching & 3.3873 & .47945 \\
\hline Module development requirements & 4.0489 & .62894 \\
\hline
\end{tabular}

Refer to the table above the need for Module of Efficacy Enhancement in English Teaching for Early Childhood Education Teacher (MEET-EceT) development is very high. Teacher have a low mean in self-assessment in teaching and self-development of emotions. 
INTERNATIONAL JOURNAL OF ACADEMIC RESEARCH IN BUSINESS AND SOCIAL SCIENCES

\section{ii) Design and Development Phase}

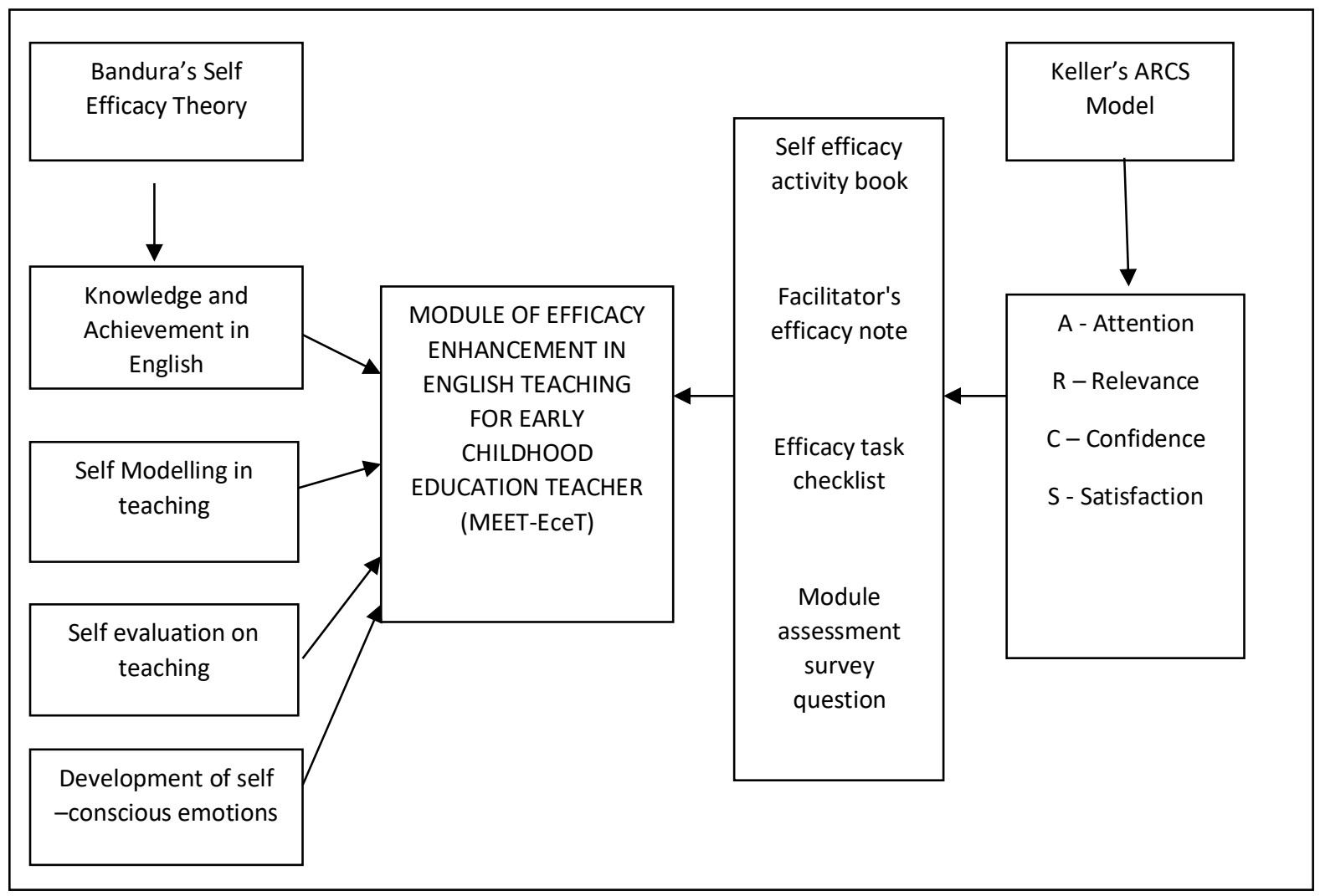

Diagram 1 MEET-EceT development based on Bandura Self Efficacy Theory and Keller's ARCS Model

There are several steps in the second phase; the validity of module content, module reliability through pilot study and module improvement after module implementation before evaluation phase. After all these steps, the module has been implemented for the actual study. 
INTERNATIONAL JOURNAL OF ACADEMIC RESEARCH IN BUSINESS AND SOCIAL SCIENCES

Vol. 8, No. 12, Dec, 2018, E-ISSN: 2222-6990 @ 2018 HRMARS

Table 2 : Content Activity Module of Efficacy Enhancement in English Teaching for Early Childhood Education Teachers (MEET-EceT)

\begin{tabular}{|l|}
\hline \multicolumn{1}{|c|}{ Sub Module / Activity } \\
\hline Strategy $1:$ Introduction to MEET-EceT \\
Activity $1:$ Build rapport \\
Activity $2:$ Getting to know Bandura's Self- Efficacy Theory \\
Activity $3:$ Teacher's Self-Efficacy \\
\hline Strategy $2:$ Knowledge and Achievement in English \\
Activity $1:$ See other people's efficacy \\
Activity $2:$ Teachers' knowledge \\
Activity $3:$ Reflective thinking \\
Activity $4:$ Self-learning \\
\hline Strategy $3:$ Self-modeling in Teaching \\
Activity $1:$ Guiding my fellow friends \\
Activity $2:$ My mentor \\
Activity $3:$ My motivation \\
Activity $4:$ Learn through observation \\
\hline Strategy $4:$ Self-evaluation on Teaching \\
Activity $1:$ Video criticism \\
Activity $2:$ Let's write a teaching plan \\
Activity $3:$ Let's practice teaching \\
Activity $4:$ Feedback is not failure \\
Activity $5:$ Others methods in teaching \\
\hline Strategy $5:$ Development of Self Conscious Emotion \\
Activity $1:$ Changes in physiology and emotions \\
Activity $2:$ Managing stress \\
Activity $3:$ The pyramid of behavioral change \\
Activity $4:$ Positive thinking of English \\
\hline Strategy $6:$ Closing - Self Transformation \\
Activity $1:$ You can do it \\
Activity $2:$ Mind transformation \\
\hline
\end{tabular}


INTERNATIONAL JOURNAL OF ACADEMIC RESEARCH IN BUSINESS AND SOCIAL SCIENCES

Vol. 8, No. 12, Dec, 2018, E-ISSN: $2222-6990$ (C) 2018 HRMARS

\section{Module Validity}

Table 3: Evaluation of MPEBI by nine experts $(n=9)$ based on Russell's (1974) module validity

Panels' Viewpoints

The content of this module is appropriate for the target population

The content of this module can be implemented practically

The content of this module corresponds with the time allocated

The content of this module can improve knowledge in the efficacy of teachers teaching English

The content of this module can reduce the level of anxiety of teachers teaching English

Total content validity of MEET-EceT

\section{Experts'}

Percentage

84.4 Accepted

84.4 Accepted

$85.5 \quad$ Accepted

86.6

Accepted

82.2

Accepted

84.6

Accepted

\section{Module Reliability}

Table 4 : Reliability of activities in six sub module / strategy

\begin{tabular}{|c|c|c|}
\hline Sub Module / Activity & $\begin{array}{l}\text { Alpha } \\
\text { Cronbach } \\
\text { Value }\end{array}$ & Result \\
\hline $\begin{array}{l}\text { Strategy } 1 \text { : Introduction to MEET-EceT } \\
\text { Activity } 1 \text { : Build rapport } \\
\text { Activity } 2: \text { Getting to know Bandura's Self- Efficacy Theory } \\
\text { Activity } 3: \text { Teacher's Self-Efficacy }\end{array}$ & .843 & Accepted \\
\hline $\begin{array}{l}\text { Strategy } 2: \text { Knowledge and Achievement in English } \\
\text { Activity } 1: \text { See other people's efficacy } \\
\text { Activity } 2: \text { Teachers' knowledge } \\
\text { Activity } 3: \text { Reflective thinking } \\
\text { Activity } 4: \text { Self-learning }\end{array}$ & .896 & Accepted \\
\hline $\begin{array}{l}\text { Strategy } 3 \text { : Self-modeling in Teaching } \\
\text { Activity } 1: \text { Guiding my fellow friends } \\
\text { Activity } 2: \text { My mentor }\end{array}$ & .924 & Accepted \\
\hline
\end{tabular}


INTERNATIONAL JOURNAL OF ACADEMIC RESEARCH IN BUSINESS AND SOCIAL SCIENCES Vol. 8, No. 12, Dec, 2018, E-ISSN: 2222-6990 @ 2018 HRMARS

\begin{tabular}{|c|c|c|}
\hline $\begin{array}{l}\text { Activity } 3 \text { : My motivation } \\
\text { Activity } 4 \text { : Learn through observation }\end{array}$ & & \\
\hline $\begin{array}{l}\text { Strategy } 4 \text { : Self-evaluation on Teaching } \\
\text { Activity } 1: \text { Video criticism } \\
\text { Activity } 2: \text { Let's write a teaching plan } \\
\text { Activity } 3: \text { Let's practice teaching } \\
\text { Activity } 4: \text { Feedback is not failure } \\
\text { Activity } 5: \text { Others methods in teaching }\end{array}$ & .932 & Accepted \\
\hline $\begin{array}{l}\text { Strategy } 5 \text { : Development of Self Conscious Emotion } \\
\text { Activity } 1: \text { Changes in physiology and emotions } \\
\text { Activity } 2: \text { Managing stress } \\
\text { Activity } 3: \text { The pyramid of behavioral change } \\
\text { Activity } 4: \text { Positive thinking of English }\end{array}$ & .888 & Accepted \\
\hline $\begin{array}{l}\text { Strategy } 6: \text { Closing - Self Transformation } \\
\text { Activity } 1: \text { You can do it } \\
\text { Activity } 2: \text { Mind transformation }\end{array}$ & .680 & Accepted \\
\hline Total content reliability of MEPBI & .967 & Accepted \\
\hline
\end{tabular}

Module improvement after pilot test 
INTERNATIONAL JOURNAL OF ACADEMIC RESEARCH IN BUSINESS AND SOCIAL SCIENCES

Vol. 8, No. 12, Dec, 2018, E-ISSN: $2222-6990$ C 2018 HRMARS

Table 5 : Content Activity Module of Efficacy Enhancement in English Teaching for Early Childhood Education Teachers (MEET-EceT) after pilot test

\begin{tabular}{|c|c|}
\hline Content Activity MEET-EceT before pilot test & Content Activity MEET-EceT after pilot test \\
\hline $\begin{array}{l}\text { Strategy } 1: \text { Introduction to MEET-EceT } \\
\text { Activity } 1: \text { Getting to know Bandura Self- } \\
\text { Efficacy Theory } \\
\text { Activity 2: Self-empowerment }\end{array}$ & $\begin{array}{l}\text { Strategy } 1 \text { : Introduction to MEET-EceT } \\
\text { Introducing a new activity } \\
\text { Activity } 1: \text { Build rapport } \\
\text { Activity } 2 \text { : Getting to know Bandura's Self- } \\
\text { Efficacy Theory } \\
\text { Activity 3: Teacher's Self-Efficacy }\end{array}$ \\
\hline $\begin{array}{l}\text { Strategy } 2: \text { Knowledge and Achievement in } \\
\text { English } \\
\text { Activity } 1: \text { Reaching for the stars } \\
\text { Activity } 2: \text { Knowledge on English pedagogy } \\
\text { Activity } 3: \text { Past teaching performance } \\
\text { Activity } 4: \text { Knowledge on content }\end{array}$ & $\begin{array}{l}\text { Strategy } 2: \text { Knowledge and Achievement in } \\
\text { English } \\
\text { Activity } 1: \text { See other people's efficacy } \\
\text { Activity } 2: \text { Teachers' knowledge } \\
\text { Activity } 3: \text { Reflective thinking } \\
\text { Activity } 4: \text { Self-learning }\end{array}$ \\
\hline $\begin{array}{l}\text { Strategy } 3 \text { : Self-modelling in Teaching } \\
\text { Activity } 1 \text { : Guiding my fellow friends } \\
\text { Activity } 2 \text { : My mentor } \\
\text { Activity } 3: \text { I am champion } \\
\text { Activity } 4 \text { : Let's practice }\end{array}$ & $\begin{array}{l}\text { Strategy } 3 \text { : Self-modelling in Teaching } \\
\text { Activity } 1: \text { Guiding my fellow friends } \\
\text { Activity } 2: \text { My mentor } \\
\text { Activity } 3: \text { My motivation } \\
\text { Activity } 4: \text { Learn through observation }\end{array}$ \\
\hline $\begin{array}{l}\text { Strategy } 4: \text { Self-evaluation on Teaching } \\
\text { Activity } 1 \text { : Video critics } \\
\text { Activity } 2: \text { Micro-teaching } \\
\text { Activity } 3: \text { Let's write teaching programme } \\
\text { Activity } 4: \text { Think positively }\end{array}$ & $\begin{array}{l}\text { Strategy } 4: \text { Self-evaluation on Teaching } \\
\text { Activity } 1 \text { : Video criticism } \\
\text { Activity } 2: \text { Let's write a teaching plan } \\
\text { Activity } 3: \text { Let's practice teaching } \\
\text { Activity } 4: \text { Feedback is not failure } \\
\text { Introducing a new activity } \\
\text { Activity } 5: \text { Other methods in teaching }\end{array}$ \\
\hline $\begin{array}{l}\text { Strategy } 5: \text { Development of Self-Emotion } \\
\text { Activity } 1: \text { Generating ideas } \\
\text { Activity } 2: \text { Managing stress } \\
\text { Activity } 3: \text { Trust on efficacy } \\
\text { Activity } 4: \text { I love English language }\end{array}$ & $\begin{array}{l}\text { Strategy } 5 \text { : Development of Self Conscious } \\
\text { Emotion } \\
\text { Activity } 1 \text { : Changes in physiology and emotions } \\
\text { Activity } 2 \text { : Managing stress } \\
\text { Activity } 3: \text { The pyramid of behavioral change } \\
\text { Activity } 4: \text { Positive thinking of English }\end{array}$ \\
\hline $\begin{array}{l}\text { Strategy } 6: \text { Closing (Individual Transformation) } \\
\text { Activity } 1: \text { My mind map } \\
\text { Activity } 2: \text { You can do it! }\end{array}$ & $\begin{array}{l}\text { Strategy } 6 \text { : Closing - Self Transformation } \\
\text { Activity } 1 \text { : You can do it! } \\
\text { Activity } 2: \text { Mind transformation }\end{array}$ \\
\hline
\end{tabular}


INTERNATIONAL JOURNAL OF ACADEMIC RESEARCH IN BUSINESS AND SOCIAL SCIENCES

Vol. 8, No. 12, Dec, 2018, E-ISSN: 2222-6990 @ 2018 HRMARS

Table 6 : Time Allocation for Each Activity in the Module of Efficacy Enhancement in English Teaching for Early Childhood Education Teachers (MEET-EceT) after pilot test

\begin{tabular}{|c|c|c|}
\hline Sub Module / Activity & $\begin{array}{l}\text { Time Allocation for } \\
\text { Each Activity Before } \\
\text { Pilot Test }\end{array}$ & $\begin{array}{l}\text { Time Allocation for } \\
\text { Each Activity After } \\
\text { Pilot Test }\end{array}$ \\
\hline $\begin{array}{l}\text { Strategy } 1: \text { Introduction to MEET-EceT } \\
\text { Introducing a new activity } \\
\text { Activity } 1: \text { Build rapport } \\
\text { Activity } 2 \text { : Getting to know Bandura's Self- Efficacy } \\
\text { Theory } \\
\text { Activity } 3: \text { Teacher's Self-Efficacy }\end{array}$ & $\begin{array}{l}60 \text { minutes } \\
60 \text { minutes }\end{array}$ & $\begin{array}{l}30 \text { minutes } \\
45 \text { minutes } \\
45 \text { minutes }\end{array}$ \\
\hline $\begin{array}{l}\text { Strategy } 2: \text { Knowledge and Achievement in English } \\
\text { Activity } 1: \text { See other people's efficacy } \\
\text { Activity } 2: \text { Teachers' knowledge } \\
\text { Activity } 3: \text { Reflective thinking } \\
\text { Activity } 4: \text { Self-learning }\end{array}$ & $\begin{array}{l}60 \text { minutes } \\
60 \text { minutes } \\
60 \text { minutes } \\
60 \text { minutes }\end{array}$ & $\begin{array}{l}45 \text { minutes } \\
45 \text { minutes } \\
45 \text { minutes } \\
45 \text { minutes }\end{array}$ \\
\hline $\begin{array}{l}\text { Strategy } 3: \text { Self-modeling in Teaching } \\
\text { Activity } 1: \text { Guiding my fellow friends } \\
\text { Activity } 2: \text { My mentor } \\
\text { Activity } 3: \text { My motivation } \\
\text { Activity } 4: \text { Learn through observation }\end{array}$ & $\begin{array}{l}60 \text { minutes } \\
60 \text { minutes } \\
60 \text { minutes } \\
60 \text { minutes }\end{array}$ & $\begin{array}{l}45 \text { minutes } \\
45 \text { minutes } \\
45 \text { minutes } \\
45 \text { minutes }\end{array}$ \\
\hline $\begin{array}{l}\text { Strategy } 4 \text { : Self-evaluation on Teaching } \\
\text { Activity } 1 \text { : Video criticism } \\
\text { Activity } 2: \text { Let's write a teaching plan } \\
\text { Activity } 3: \text { Let's practice teaching } \\
\text { Activity } 4 \text { : Feedback is not failure } \\
\text { Introducing a new activity } \\
\text { Activity } 5 \text { : Others methods in teaching }\end{array}$ & $\begin{array}{l}60 \text { minutes } \\
60 \text { minutes } \\
60 \text { minutes } \\
60 \text { minutes }\end{array}$ & $\begin{array}{l}60 \text { minutes } \\
30 \text { minutes } \\
120 \text { minutes } \\
30 \text { minutes } \\
90 \text { minutes }\end{array}$ \\
\hline $\begin{array}{l}\text { Strategy } 5 \text { : Development of Self Conscious Emotion } \\
\text { Activity } 1 \text { : Changes in physiology and emotions } \\
\text { Activity } 2: \text { Managing stress } \\
\text { Activity } 3: \text { The pyramid of behavioral change } \\
\text { Activity } 4: \text { Positive thinking of English }\end{array}$ & $\begin{array}{l}60 \text { minutes } \\
60 \text { minutes } \\
60 \text { minutes } \\
60 \text { minutes }\end{array}$ & $\begin{array}{l}45 \text { minutes } \\
45 \text { minutes } \\
45 \text { minutes } \\
45 \text { minutes }\end{array}$ \\
\hline $\begin{array}{l}\text { Strategy } 6: \text { Closing - Self Transformation } \\
\text { Activity } 1: \text { You can do it } \\
\text { Activity } 2: \text { Mind transformation }\end{array}$ & $\begin{array}{l}60 \text { minutes } \\
60 \text { minutes }\end{array}$ & $\begin{array}{l}45 \text { minutes } \\
45 \text { minutes }\end{array}$ \\
\hline Total hours MEET-EceT activities & 20 hours & 18 hours \\
\hline
\end{tabular}


INTERNATIONAL JOURNAL OF ACADEMIC RESEARCH IN BUSINESS AND SOCIAL SCIENCES Vol. 8, No. 12, Dec, 2018, E-ISSN: 2222-6990 @ 2018 HRMARS

\section{iii) Evaluation Phase}

Table 7 : Mean differences between treatment group and control group Treatment Group

\begin{tabular}{|l|c|c|c|c|}
\hline \multicolumn{1}{|c|}{ Domain } & $\begin{array}{c}\text { Mean } \\
\text { Pre }\end{array}$ & $\begin{array}{c}\text { Mean } \\
\text { Post }\end{array}$ & $\begin{array}{c}\text { Mean } \\
\text { Difference }\end{array}$ & $\begin{array}{c}\text { Percent change of } \\
\text { mean }\end{array}$ \\
\hline Efficacy Belief & 3.3892 & 4.0135 & 0.6243 & $12.486 \%$ \\
\hline Efficacy practice & 3.0478 & 3.9751 & 0.9273 & $18.546 \%$ \\
\hline Efficacy of teaching & 3.2185 & 3.9943 & 0.7758 & $15.516 \%$ \\
\hline Anxiety & 3.1508 & 2.4485 & -0.7023 & $-14.046 \%$ \\
\hline Efficacy Attitude & 3.1960 & 3.4790 & 0.283 & $5.66 \%$ \\
\hline
\end{tabular}

\begin{tabular}{|c|c|c|c|c|}
\hline \multicolumn{5}{|c|}{ Control group } \\
\hline Domain & $\begin{array}{l}\text { Mean } \\
\text { Pre }\end{array}$ & $\begin{array}{c}\text { Mean } \\
\text { Post }\end{array}$ & $\begin{array}{c}\text { Mean } \\
\text { Difference }\end{array}$ & $\begin{array}{c}\text { Percent change of } \\
\text { mean }\end{array}$ \\
\hline Efficacy Belief & 3.4673 & 3.7387 & 0.2714 & $5.428 \%$ \\
\hline Efficacy practice & 3.3798 & 3.6747 & 0.2949 & $5.898 \%$ \\
\hline Efficacy of teaching & 3.4236 & 3.7067 & 0.2831 & $5.662 \%$ \\
\hline Anxiety & 3.1798 & 3.1818 & 0.002 & $0.04 \%$ \\
\hline Efficacy Attitude & 3.3423 & 3.5318 & 0.1895 & $3.79 \%$ \\
\hline
\end{tabular}

Table 8 : Result of t-test

\begin{tabular}{|l|c|c|c|c|c|c|}
\hline & Min & Std.Dev & $\begin{array}{c}\text { Std. } \\
\text { Error }\end{array}$ & $\mathrm{t}$ & $\mathrm{df}$ & $\begin{array}{c}\text { Significant } \\
2 \text { tailed }\end{array}$ \\
\hline Efficacy Belief & -.44781 & .47464 & .05842 & -7.665 & 65 & .000 \\
\hline Efficacy practice & -.61111 & .57832 & .07119 & -8.585 & 65 & .000 \\
\hline $\begin{array}{l}\text { Efficacy of } \\
\text { teaching }\end{array}$ & -.52946 & .45957 & .05657 & -9.360 & 65 & .000 \\
\hline Anxiety & .35017 & .68913 & .08483 & 4.128 & 65 & .000 \\
\hline Efficacy Attitude & -.23625 & .28853 & .03552 & -6.652 & 65 & .000 \\
\hline
\end{tabular}

The $t$-value for the self-efficacy belief was -7.665 and significant at $p<0.001$. This shows that the level of teacher's efficacy belief after attending the training is significantly higher as compared to before, with a mean difference of 0.6243. The $t$-value for efficacy practice was -8.585 and significant at $p<0.001$. This shows that the level of teaching efficacy practice after attending the training is significantly higher as compared to before, with a mean difference of 0.9273 . 
The $t$-value for anxiety level was 4.128 and significant at $p<0.001$. This indicates that the teacher's anxiety level after attending the training is significantly lower, with a mean difference of 0.7023 . The $t$-value for the teaching efficacy (self-efficacy belief + teaching efficacy practice) was 9.360 and significant at $p<0.001$. This shows that the teachers' teaching efficacy after attending the training is significantly higher than before, with a mean difference of 0.7758 . The $t$-value for teachers' attitude towards English teaching (self-efficacy belief + teaching efficacy practice + anxiety level) was -6.652 and significant at $p<0.001$. This shows that the teachers' attitude after the training was significantly better than before, with a mean difference of 0.283 .

Qualitative data also taken as supportive data. Interview were conducted on eight teacher and two facilitator. Interview analysis is divided into three; module advantages, module weakness and module improvement. Table 9 are themes emerging based on the interview conducted;

Table 9 : Interview analysis data

\begin{tabular}{|c|c|c|c|}
\hline & Module Advantages & Module Weakness & Module Improvement \\
\hline Teacher & $\begin{array}{l}\text { Personality } \\
\text { changes } \\
\text { - Enhanced } \\
\text { knowledge and } \\
\text { skills } \\
\text { - Teaching become } \\
\text { more attractive } \\
\text { - Positive emotional } \\
\text { development }\end{array}$ & $\begin{array}{l}\text { - } \text { Need to add } \\
\text { simulation } \\
\text { activities } \\
\text { - } \text { Need longer time }\end{array}$ & $\begin{array}{l}\text { - Various } \\
\text { activities such as } \\
\text { role play, } \\
\text { drama, } \\
\text { conversation } \\
\text { play and so on }\end{array}$ \\
\hline Facilitator & $\begin{array}{l}\text { - Suitability of } \\
\text { module for training } \\
\text { - Enhanced teachers } \\
\text { knowledge and } \\
\text { skills } \\
\text { - Easy to follow and } \\
\text { interesting }\end{array}$ & $\begin{array}{l}\text { - Module need } \\
\text { more time for } \\
\text { implementation }\end{array}$ & $\begin{array}{l}\text { - Module content } \\
\text { uses a lot of } \\
\text { terms that are } \\
\text { rarely heard, so } \\
\text { there needs to } \\
\text { be a more } \\
\text { detailed } \\
\text { description }\end{array}$ \\
\hline
\end{tabular}

\section{Conclusion}

In conclusion, MEET-EceT can improve the early childhood education teachers' attitude towards English language, in terms of cognitive, behavioural and affective aspects. This module is useful to enhance the knowledge and efficacy belief in teaching English thus increase the efficiency and motivation during teaching practice, besides reducing the anxiety level among the preschool teachers while teaching in English. 
INTERNATIONAL JOURNAL OF ACADEMIC RESEARCH IN BUSINESS AND SOCIAL SCIENCES

Vol. 8, No. 12, Dec, 2018, E-ISSN: $2222-6990$ C 2018 HRMARS

\section{Corresponding Author}

Nur Nazuha Beevi Abdul Aziz

National Child Development Research Centre

Sultan Idris Education University,

35900 Tanjong Malim

Perak, Malaysia

Email: bibiyana_aziz@yahoo.com

\section{References}

Abdul Aziz, N.N.B. \& Mamat, N. (2015). Efikasi Kendiri Guru dan Hubungannya Dengan Pencapaian Akademik Di Sekolah. Prosiding Seminar Kebangsaan Pascasiswazah Asuhan dan Didikan Kanak-Kanak. Tanjong Malim : Universiti Pendidikan Sultan Idris.

Abdul Aziz, N.N.B. \& Mamat, N. (2015). Pembinaan Modul Efikasi Pengajaran dan Pembelajaran Bahasa Inggeris Prasekolah Dalam Meningkatkan Tahap Efikasi Guru dan Tahap Penguasaan Kosa Kata Bahasa Inggeris di Kalangan Kanak-Kanak Prasekolah. Prosiding Seminar Penyelidikan Pendidikan Kebangsaan IPG Kampus Zon Utara 2015. Pulau Pinang : Institut Pendidikan Guru Tuanku Bainun.

Abdul Aziz, N.N.B. \& Mamat, N. (2017). Pembangunan Modul Peningkatan Efikasi Mengajar Bahasa Inggeris Guru Prasekolah (MEP-BI) : Kajian Rintis. Prosiding Seminar Pascasiswazah Kebangsaan 2017. Tanjong Malim : Universiti Pendidikan Sultan Idris.

Abdul Aziz, N.N.B \& Mamat, N. (2017). Analisis Keperluan : Pembangunan Modul Efikasi Pengajaran Bahasa Inggeris Guru Prasekolah. Proceedings National Conference on Education Social Science, Engineering and Technology (NCESET 2017). Kedah : Association of Malaysian Researchers \& Social Services (AMRASS).

Abdul Aziz, N.N.B. \& Mamat, N. (2017). Kesahan dan Kebolehpercayaan Soal Selidik Efikasi Pengajaran Bahasa Inggeris Dalam Kalangan Guru Prasekolah. Prosiding Seminar Wacana Pendidikan 2017 (SWAPEN). Kedah : Institut Pengurusan dan Integriti.

Abdul Aziz, N.N.B. \& Mamat, N. (2018). Kajian Reka Bentuk dan Pembangunan Modul Peningkatan Efikasi Mengajar Bahasa Inggeris (MPEBI) Guru Prasekolah. International Conference On The Future Of Education (IConFED). Pulau Pinang : Hotel Bayview.

Abdul Aziz, N.N.B. \& Mamat, N. (2018). Modul Peningkatan Efikasi Mengajar Bahasa Inggeris (MPEBI) Guru Pendidikan Awal Kanak-Kanak : Kajian Rintis. International Conference On Teacher Learning And Develoment (ICTLD). Kuala Lumpur : Hotel Royale Chulan. 
INTERNATIONAL JOURNAL OF ACADEMIC RESEARCH IN BUSINESS AND SOCIAL SCIENCES

Vol. 8, No. 12, Dec, 2018, E-ISSN: $2222-6990$ C 2018 HRMARS

Abdul Rahman, M.N. (2016). Application of Fuzzy Delphi Approach in Designing Homeschooling Education for Early Childhood Islamic Education. Tesis PhD. Kuala Lumpur : Universiti Malaysia.

Bandura, A. (1997). Self-Efficacy : The exercise of control. New York : Freeman.

Johari, K., Ismail, Z., Osman, S., \& Othman, Tajuddin. (2009). Pengaruh jenis latihan guru dan pengalaman mengajar terhadap efikasi guru sekolah menengah. Jurnal Pendidikan Malaysia. $34(2), 3-14$.

Kementerian Pelajaran Malaysia. (2009). Dokumen standard prasekolah : Kurikulum Standard Prasekolah Kebangsaan. Kuala Lumpur : Bahagian Pembangunan Kurikulum, Kementerian Pelajaran Malaysia.

Mohamed Arip, M. A. S. (2010). Kesan kelompok bimbingan terapi kognitif-tingkahlaku ke atas konsep kendiri, kelangsangan dan daya tahan remaja. Tesis PhD, Fakulti Pendidikan, Universiti Kebangsaan Malaysia.

Mohamed Arip, M. A. S. (2018). Pembinaan dan Pengujian Modul. Selangor : I Psychology and Counseling Academy.

Mohd Noah, S. (2005). Pengujian dan Penilaian Kaunseling : Teori dan Aplikasi. Serdang : Universiti Putra Malaysia.

Mohd Noah, S. \& Ahmad, J. (2005).Pembinaan Modul. Bagaimana membina modul latihan dan modul akademik. Serdang: Penerbit UPM.

Richey, R.C., \& Klein, J.D. (2007). Design and developmental research. New York, NY : Routledge.

Siraj, S., Alias, N., Dewitt, D., \& Hussin, Z. (2013). Design and developmental research : Emergent trends in educational research. Kuala Lumpur : Pearson Malaysia.

Thompson. G. (2016). Japanese High School English Teachers' Self-Efficacy Beliefs About Teaching English. PhD Theses, Faculty of Education : Queensland University of Technology.

Tschannen-Moran, M., \& Woolfolk Hoy, A. (2001). Teacher efficacy : Capturing and elusive construct. Teaching and Teacher Education, 17, 783 - 805. 